\title{
More Evidence on the Dollar Risk Premium in the Foreign Exchange Market
}

\author{
Citation for published version (APA):
}

Bams, W. F. M., Walkowiak, K., \& Wolff, C. C. P. (2004). More Evidence on the Dollar Risk Premium in the Foreign Exchange Market. Journal of International Money and Finance, 2004(23), 271-282. https://doi.org/10.1016/j.jimonfin.2003.12.004

Document status and date:

Published: 01/01/2004

DOI:

10.1016/j.jimonfin.2003.12.004

Document Version:

Publisher's PDF, also known as Version of record

\section{Please check the document version of this publication:}

- A submitted manuscript is the version of the article upon submission and before peer-review. There can be important differences between the submitted version and the official published version of record.

People interested in the research are advised to contact the author for the final version of the publication, or visit the DOI to the publisher's website.

- The final author version and the galley proof are versions of the publication after peer review.

- The final published version features the final layout of the paper including the volume, issue and page numbers.

Link to publication

\footnotetext{
General rights rights.

- You may freely distribute the URL identifying the publication in the public portal. please follow below link for the End User Agreement:

www.umlib.nl/taverne-license

Take down policy

If you believe that this document breaches copyright please contact us at:

repository@maastrichtuniversity.nl

providing details and we will investigate your claim.
}

Copyright and moral rights for the publications made accessible in the public portal are retained by the authors and/or other copyright owners and it is a condition of accessing publications that users recognise and abide by the legal requirements associated with these

- Users may download and print one copy of any publication from the public portal for the purpose of private study or research.

- You may not further distribute the material or use it for any profit-making activity or commercial gain

If the publication is distributed under the terms of Article $25 \mathrm{fa}$ of the Dutch Copyright Act, indicated by the "Taverne" license above, 


\title{
More evidence on the dollar risk premium in the foreign exchange market
}

\author{
Dennis Bams ${ }^{\mathrm{a}, \mathrm{b}}$, Kim Walkowiak ${ }^{\mathrm{b}}$, Christian C.P. Wolff ${ }^{\mathrm{b}, \mathrm{c}, *}$ \\ a $I N G$ Re, The Netherlands \\ b Limburg Institute of Financial Economics (LIFE), Maastricht University, P. O. Box 616, 6200 MD \\ Maastricht, The Netherlands \\ c CEPR, The Netherlands
}

\begin{abstract}
In this article, we develop and estimate an econometric panel data model to capture the common dynamics in dollar risk premia in various forward foreign exchange rates. The common component in the dollar risk premium is highly significant and embodies a common pattern of positive serial correlation (persistence) for the pound, the yen and the mark. Interestingly, our results indicate that the dynamics of the forward prediction error can be attributed almost exclusively to this dollar-related common component. Our evidence also suggests that the three different foreign currencies' dollar risk premia 'respond' to the common factor to different degrees.
\end{abstract}

(C) 2004 Elsevier Ltd. All rights reserved.

JEL classification: $\mathrm{F} 31 ; \mathrm{G} 15$

Keywords: Forward currency; Time-varying risk premium; Panal data analysis

\section{Introduction}

In the international financial economics literature the relation between forward and spot exchange rates is perhaps one of the most often investigated. A prominent empirical finding in this literature is forward discount bias. In addition to forward exchange unbiasedness being rejected, it is often found that the change in the future exchange rate is negatively related to the forward discount, following Fama

\footnotetext{
* Corresponding author. Limburg Institute of Financial Economics (LIFE), Maastricht University, P.O. Box 616, 6200 MD Maastricht, The Netherlands. Tel.: +31-43-388-3556; fax: +31-43-388-4875.

E-mail address: c.wolff@berfin.unimaas.nl (C.C.P. Wolff).
} 
(1984). Explanations for forward discount bias fall into two broad classes: (1) the presence of forecast errors and (2) the existence of time-varying risk premia.

The first class, forecast errors, comprises statistical measurement problems and possible irrationality of expectations. Measurement difficulties arise when the distribution of shocks that effect the economy undergo infrequent shifts. Natural disasters and monetary policy regime changes are examples of such shifts. When market participants anticipate a future discrete shift in the policy, but this shift did not materialize within the sample period, the measurement problem is referred to as a peso problem, Krasker (1980). In the opposite case, when a shift has occurred and people learn about this change slowly, and therefore adapt their expectations slowly, it is called a learning problem, Lewis (1995). Irrationality of survey-based exchange rate expectations was first documented by Froot and Frankel (1989). Cavaglia et al. (1994) questioned the Frankel and Froot (1989) results and established that forward discount bias is attributable to both irrationality of expectations and time-varying risk premia.

This brings us to the second class of explanations: the presence of time-varying risk premia in the pricing of forward foreign exchange, in a setting where expectations are assumed to be rational. Useful surveys in this area were provided by Hodrick (1987) and Engel (1996). Nijman et al. (1993) and Wolff (1987), using monthly data, demonstrated that low-order autoregressive (AR) models can represent the risk premium quite adequately. Their, and others', measurements of risk premia show that they usually fluctuate around zero and that confidence intervals around these risk premia are large, partly due to parameter uncertainty in the risk premium models.

In this paper, we will focus on the second class of explanations for forward discount bias. Our aim is to learn more about the properties of the risk premium. The risk premium, of course, is not directly observable and assumptions are required to learn about its properties. Conditional on the assumption of rational expectations, we will explore the properties of risk premia in the context of a common-factor panel data framework. This is achieved by a panel risk premium specification, in which the data for different currencies (all expressed in dollar values), are pooled and time variation in the risk premia for individual currencies relative to the dollar is driven by a single, common factor which is modeled as an $\mathrm{AR}(1)$ variate. We allow exchange rates to exhibit different exposures to this risk premium. Our approach allows us to focus on the dynamics of the risk premium directly, as opposed to the approach of Huisman et al. (1998), who tested for uncovered interest parity using a panel data model. The introduction of a common component in our model implies that possible other factors are treated as white noise. Interestingly, our empirical results lend support to this assumptions.

The paper is presented in four sections. In Section 2 the model is set forth and the econometric framework is explained. In Section 3 the data are described and summary statistics are provided. Section 4 is devoted to the estimation results; here the implications for the risk premium are described in detail. Section 5 concludes. 


\section{The risk premium model and its econometric implications}

Let $\mathrm{S}_{\mathrm{i}, \mathrm{t}}$ denote the natural logarithm of currency $\mathrm{i}$, expressed in dollars, at time $\mathrm{t}$. The one-period forward rate for currency $i$, quoted at time $t$, is denoted by $F_{i, t}$. Given our rational expectations assumption, we can define the risk premium in this context as

$$
R P_{i, t}=F_{i, t}-E_{t}\left[S_{i, t+1}\right]
$$

where $\mathrm{RP}_{\mathrm{i}, \mathrm{t}}$ is the risk premium at time $\mathrm{t}$ associated with currency $\mathrm{i}$ and $\mathrm{E}_{\mathrm{t}}[$. denotes an expectation conditional on information available at time t. By adding $\mathrm{S}_{\mathrm{i}, \mathrm{t}+1}-\mathrm{S}_{\mathrm{i}, \mathrm{t}}$ on both sides of eq. (1), and rearranging, we obtain

$$
\mathrm{S}_{\mathrm{i}, \mathrm{t}+1}-\mathrm{S}_{\mathrm{i}, \mathrm{t}}=\mathrm{F}_{\mathrm{i}, \mathrm{t}}-\mathrm{S}_{\mathrm{i}, \mathrm{t}}-\mathrm{RP}_{\mathrm{i}, \mathrm{t}}+\mathrm{S}_{\mathrm{i}, \mathrm{t}+1}-\mathrm{E}\left[\mathrm{S}_{\mathrm{i}, \mathrm{t}+1}\right] .
$$

Eq. (2) is often implemented empirically in the following way in order to test for unbiasedness

$$
\mathrm{S}_{\mathrm{i}, \mathrm{t}+1}-\mathrm{S}_{\mathrm{i}, \mathrm{t}}=\alpha+\beta\left(\mathrm{F}_{\mathrm{i}, \mathrm{t}}-\mathrm{S}_{\mathrm{i}, \mathrm{t}}\right)+\varepsilon_{\mathrm{t}+1}
$$

where $\varepsilon_{t+1}$ is an uncorrelated, zero mean process. Empirical tests routinely reject the null hypothesis that the forward rate is a conditionally unbiased predictor of future spot rates, $\mathrm{H}_{0}:[\alpha, \beta]=[0,1]$.

Eq. (2) will be the basis of the measurement equation of our econometric model.For convenience, we rewrite eq. (2) as

$$
\mathrm{Y}_{\mathrm{i}, \mathrm{t}+\mathrm{l}}=\mathrm{X}_{\mathrm{i}, \mathrm{t}}-\mathrm{R} \mathrm{P}_{\mathrm{i}, \mathrm{t}}+\mathrm{u}_{\mathrm{i}, \mathrm{t}+1}
$$

where $\mathrm{Y}_{\mathrm{i}, \mathrm{t}+1}=\left(\mathrm{S}_{\mathrm{i}, \mathrm{t}+1}-\mathrm{S}_{\mathrm{i}, \mathrm{t}}\right), \mathrm{X}_{\mathrm{i}, \mathrm{t}}=\left(\mathrm{F}_{\mathrm{i}, \mathrm{t}}-\mathrm{S}_{\mathrm{i}, \mathrm{t}}\right)$ and $\mathrm{u}_{\mathrm{i}, \mathrm{t}+1}=\left(\mathrm{S}_{\mathrm{i}, \mathrm{t}+1}-\mathrm{E}\left[\mathrm{S}_{\mathrm{i}, \mathrm{t}+1}\right]\right)$. The variable $u_{t, t+1}$ represents an uncorrelated errors sequence. As a consequence of our rational expectations assumption, the error term has the interpretation of an innovation. The risk premium in eq. (4) is not yet identified because it cannot be discerned from the error term. It is clear, however, that any persistence in a time series $Y_{i, t+1}-X_{i, t}$ must be attributed to a risk premium rather than to the error term $u_{i, t+1}$, see Wolff $(1987,2000)$. Therefore, the time variation in the risk premium is discernable. Following univariate findings by Cavaglia et al. (1994); Nijman et al. (1993) and Wolff (1987), we model the common factor in the dollar risk premia as an $\mathrm{AR}(1)$ variate. The $\mathrm{AR}(1)$ specification is supported by the autocorrelations that are presented with the description of our dataset in Section 3. The 'exposure' of the different currencies to this common factor is allowed to be different. The complete model reads:

$$
\begin{aligned}
& \mathrm{Y}_{\mathrm{t}+1}=\mathrm{d}+\mathrm{X}_{\mathrm{t}}+\theta \lambda_{\mathrm{t}}+\mathrm{u}_{\mathrm{t}+1}, \\
& \lambda_{\mathrm{t}}=\gamma \lambda_{\mathrm{t}-1}+\eta_{\mathrm{t}}, \\
& \mathrm{u}_{\mathrm{t}} \sim \mathrm{N}(0, \Sigma), \\
& \eta_{\mathrm{t}} \sim \mathrm{N}\left(0, \xi^{2}\right),
\end{aligned}
$$

where the vectors $Y_{t}=\left[Y_{1, t} \ldots Y_{N, t}\right]^{\prime}, X_{t}=\left[X_{1, t} \ldots X_{N, t}\right]^{\prime}, u_{t}=\left[u_{1, t} \ldots u_{N, t}\right]^{\prime}, \theta=$ $\left[\theta_{1} \ldots \theta_{N}\right]^{\prime}$ and $d=\left[d_{1} \ldots d_{N}\right]^{\prime}$ are introduced. The latter is a vector of intercepts in 
the measurement equation. The number $\mathrm{N}$ represents the number of available currencies (excluding the US dollar) over a time span of T observations. The scalar $\lambda_{t}$ represents the common component in the risk premia for various currencies vis-avis the US Dollar at time t. It takes account of the common time series behavior in all risk premia, and $\theta$ models a currency's specific 'exposure' to the common component. Finally, $\Sigma$ denotes a $(\mathrm{N} \times \mathrm{N})$ covariance matrix and $\xi^{2}$ represents the variance of $\eta_{\mathrm{t}}$. Eq. (5) is the measurement equation of the system and eq. (6), the state transition equation, captures the dynamics of the common component, which is not itself directly observable. Note that the error term $u_{t+1}$ is assumed to be i.i.d. This implies that the dynamics of the dollar risk premia for the three foreign currencies are governed entirely by the common, dollar-related common factor. Interestingly, our empirical results in Section 4 of the paper lend support to this assumption. It is also assumed that the error term $\mathrm{u}_{\mathrm{t}+1}$ and $\lambda_{\mathrm{r}}$ are independently distributed for all r,t. A normalization restriction $\theta_{\mathrm{BP} / \mathrm{US}}=1$ is imposed, which implies that the time variation of the risk premium associated with currency $\mathrm{i}$ is scaled relative to the time variation of the British Pound through the parameters $\theta_{\mathrm{i}}$. The model, as presented by eqs. (5)-(8), is in state-space form and the unknown parameters d, $\theta, \gamma, \Sigma$ and $\xi^{2}$ can be estimated through maximum likelihood procedures. The covariance matrix of the parameter estimates follows as the negative of the inverse of the expected Hessian matrix. Evaluation of the loglikelihood function is achieved using the Kalman filter.

\section{The data}

In this study we employ end-of-the month spot and forward exchange rates that cover the period June 1978 through March 1996. The maturity of the forward rates is one month. All raw data are London closing mid-prices against the Pound Sterling, obtained from Datastream, for Germany, Japan, and the United States. In our empirical analysis below, all exchange rates were crossed in order to report our results in U.S. Dollar terms. The data are sampled following the procedure described in Bekaert and Hodrick (1992), using exact delivery dates of the forward exchange contracts. To find the delivery date on a forward contract made today, one first finds today's spot value date, which is two business days in the future. Delivery takes place on the calendar day in the next month that corresponds to the current spot value date, under the condition that the delivery day is a business day. If not, delivery takes place on the next business day if it falls within the same calendar month. If the latter condition is not met, delivery takes place on the first previous business day. This rule is followed except when the spot value day is the last business day of the current month, in which case the forward value date is the last business day of the next month. Unless one follows these rules precisely, measurement error is introduced into the analysis.

Tables 1-3 provide summary statistics for the spot rate, the forward rate, the forward discount, the continuously compounded rate of depreciation, and the forward prediction error for the different currencies. Recall that the data were trans- 
Table 1

Summary statistics of spot rate and forward rate

\begin{tabular}{|c|c|c|c|c|c|c|}
\hline & \multicolumn{3}{|c|}{ Spot rate, $\mathrm{S}_{\mathrm{t}}$} & \multicolumn{3}{|c|}{ Forward rate, $F_{t}$} \\
\hline & $\mathrm{DM} / \mathrm{US}$ & JY/US & $\mathrm{BP} / \mathrm{US}$ & $\mathrm{DM} / \mathrm{US}$ & JY/US & $\mathrm{BP} / \mathrm{US}$ \\
\hline Minimum & 0.315 & 4.426 & -0.893 & 0.313 & 4.428 & -0.8889 \\
\hline Maximum & 1.215 & 5.626 & -0.066 & 1.206 & 5.621 & -0.0726 \\
\hline Mean & $\begin{array}{l}0.658^{* *} \\
(0.015)\end{array}$ & $\begin{array}{l}5.090^{* *} \\
(0.022)\end{array}$ & $\begin{array}{l}-0.517^{* *} \\
(0.011)\end{array}$ & $\begin{array}{l}0.657^{* *} \\
(0.015)\end{array}$ & $\begin{array}{l}5.089^{* *} \\
(0.022)\end{array}$ & $\begin{array}{l}-0.5177^{* *} \\
(0.0109)\end{array}$ \\
\hline Variance & $\begin{array}{l}0.047^{* *} \\
(0.000)\end{array}$ & $\begin{array}{l}0.107^{* *} \\
(0.001)\end{array}$ & $\begin{array}{l}0.025^{* *} \\
(0.000)\end{array}$ & $\begin{array}{l}0.045^{* *} \\
(0.000)\end{array}$ & $\begin{array}{l}0.107^{* *} \\
(0.001)\end{array}$ & $\begin{array}{l}0.0252 \\
(0.001)\end{array}$ \\
\hline Skewness & $0.643^{* *}$ & -0.076 & -0.242 & $0.643^{* *}$ & -0.101 & -0.2485 \\
\hline Kurtosis & 2.452 & $1.661^{* *}$ & 3.042 & 2.459 & $1.681^{* *}$ & 2.9833 \\
\hline
\end{tabular}

Note. $\mathrm{DM}=$ German mark, JY = Japanese yen, $\mathrm{BP}=$ British pound, US = U.S. dollar, Standard errors are denoted in parentheses.

Data are annualized monthly data, expressed in percent.

* Significant at the 5\% level.

** Significant at the $1 \%$ level.

formed to natural logarithms. Note in Table 2 that $\Delta \mathrm{S}_{\mathrm{i}, \mathrm{t}}$, the continuously compounded exchange rate return, which is the left-hand-side variable in eqs. (1) and (4), shows almost no excess kurtosis, with the exception of the sterling/dollar exchange rate. The same holds for the forward prediction errors in Table 3.

To offer some insight into the (non)stationarity of the data, the first order autocorrelation coefficient and the Phillips-Perron statistic for unit roots are presented in Table 4. In this table we test the null hypothesis that the autocorrelation coefficient equals one, and, for the Phillips-Perron test, the null hypothesis that there is a unit root. The values of the autocorrelation coefficients for the log levels of the spot and forward exchange rates are close to unity and suggest nonstationarity of the sequences over time. This suggestion is supported by the relevant values of the Philips-Perron test statistics, which do not reject the presence of a unit root. Subtraction of the lagged spot rate, i.e. focusing on differences rather than levels, eliminates the nonstationarity problem, as is indicated by the Phillips-Perron statistics. In the table we also study the dynamics of the forward forecast error. Note that positive serial correlation is present significantly, already in this simple univariate setting, for the yen and the mark. Given our hypothesis of rational expectations, this serial correlation can be interpreted as a reflection of persistence (positive serial correlation) in the dynamics of the underlying risk premia, see Wolff (1987).

Fig. 1 shows the forward prediction errors for the three exchange rates relative to the US Dollar for the last five years of the sample, March 1991 to March 1996. The figure suggests quite clearly that there is a common component present in the prediction errors. This is a suggestion that we follow up on in the full panel data model, which incorporates an explicit dynamic structure for a common component. 


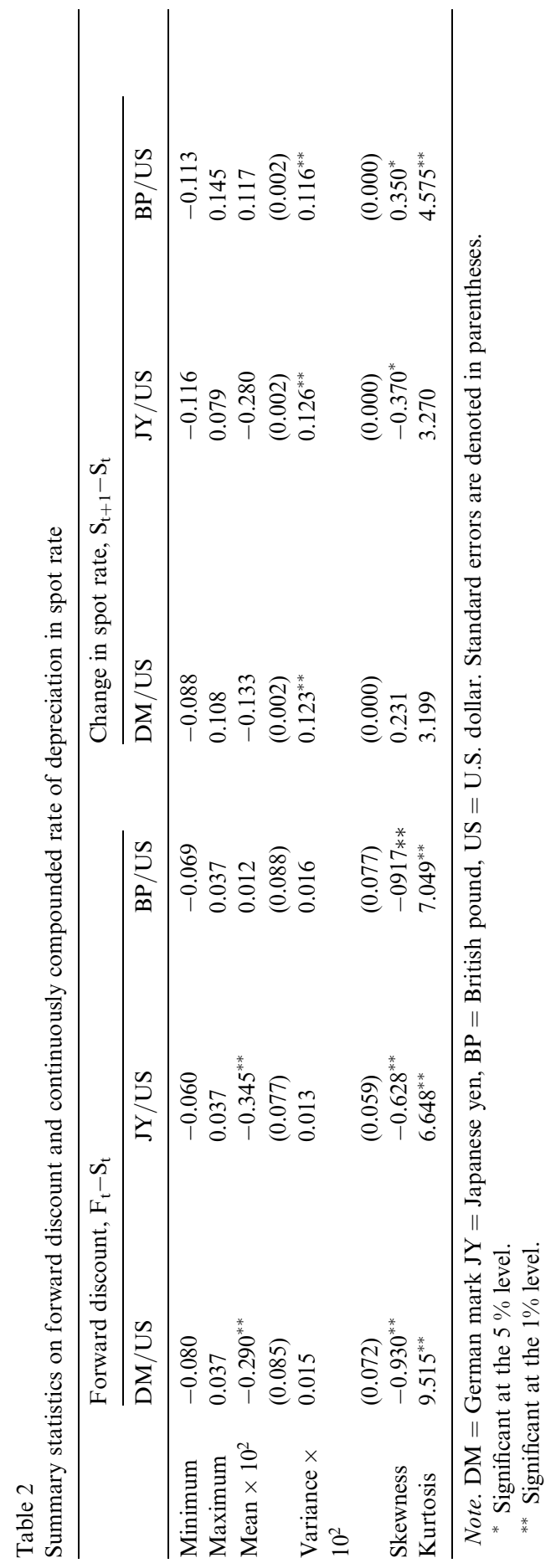


Table 3

Summary statistics on the forward prediction error, $\mathrm{S}_{\mathrm{t}+1}-\mathrm{F}_{\mathrm{t}}$

\begin{tabular}{llll}
\hline & DM/US & JY/US & BP/US \\
\hline Minimum & -0.080 & -0.114 & -0.107 \\
Maximum & 0.113 & 0.108 & 0.146 \\
Mean $\times 10^{2}$ & 0.157 & 0.064 & 0.105 \\
& $(0.256)$ & $(0.263)$ & $(0.257)$ \\
Variance $\times 10^{2}$ & 0.140 & 0.147 & 0.141 \\
Skewness & $(0.658)$ & $(0.691)$ & $(0.660)$ \\
Kurtosis & 0.306 & -0.158 & $0.465^{* *}$ \\
\end{tabular}

Note.-DM = German mark, $\mathrm{JY}=$ Japanese yen, $\mathrm{BP}=$ British pound, $\mathrm{US}=\mathrm{U} . \mathrm{S}$. dollar. $\quad$ Standard errors are denoted in parentheses.

* Significant at the 5\% level.

** Significant at the $1 \%$ level.

\section{Empirical results}

In this section, we present our estimation results. Before turning to the full panel data model, taking advantage of all the data and of common patterns across currencies, we will briefly focus on the simple univariate case. This will allow us to obtain preliminary estimates and help to illustrate the role of the common component. Let $\mathrm{N}$ equal 1 and normalize $\theta$ to unity in the eqs. (5)-(8). The univariate case of the risk premium model then reduces to the following process

$$
\mathrm{PE}_{\mathrm{t}+1}=\mathrm{d}(1-\gamma)+\gamma \mathrm{PE}_{\mathrm{t}}+\mathrm{u}_{\mathrm{t}+1}-\gamma \mathrm{u}_{\mathrm{t}}+\eta_{\mathrm{t}}
$$

where $\mathrm{PE}_{\mathrm{t}+1}$ denotes the forward prediction error, $\mathrm{S}_{\mathrm{t}+1}-\mathrm{F}_{\mathrm{t}}$, or, equivalently, $\mathrm{Y}_{\mathrm{t}+1}-\mathrm{X}_{\mathrm{t}}$. Since both $\mathrm{u}_{\mathrm{t}}$ and $\eta_{\mathrm{t}}$ represent standard i.i.d error terms and

Table 4

First-order autocorrelations and PhillipsPerron statistics

\begin{tabular}{llllll}
\hline & $\mathrm{S}$ & $\mathrm{F}$ & $\Delta \mathrm{S}$ & $(\mathrm{F}-\mathrm{S})$ & $\left(\mathrm{S}_{\mathrm{t}+1}-\mathrm{F}_{\mathrm{t}}\right)$ \\
\hline $\begin{array}{l}\text { DM/US } \\
\begin{array}{l}\text { Auto- } \\
\text { correlation }\end{array}\end{array}$ & 0.997 & 0.997 & 0.021 & 0.092 & 0.098 \\
$\begin{array}{l}\text { PP-statistic } \\
\text { JY/US }\end{array}$ & -2.224 & -2.224 & $-205.814^{* *}$ & $-196.486^{* *}$ & $-190.090^{* *}$ \\
$\begin{array}{l}\text { Auto- } \\
\text { correlation }\end{array}$ & 0.999 & 0.999 & 0.102 & 0.004 & 0.184 \\
$\begin{array}{l}\text { PP-statistic } \\
\text { BP/US }\end{array}$ & -0.491 & -0.673 & $-193.697^{* *}$ & & $-174.122^{* *}$ \\
$\begin{array}{l}\text { Auto- } \\
\text { correlation }\end{array}$ & 0.996 & 0.996 & 0.093 & $-214.594^{* *}$ & 0.196 \\
PP-statistic & -5.056 & -5.077 & $-193.498^{* *}$ & 0.110 & $-171.876^{* *}$
\end{tabular}

* PP-statistic significant at the 5\% level.

** PP-statistic significant at the 1\% level. 


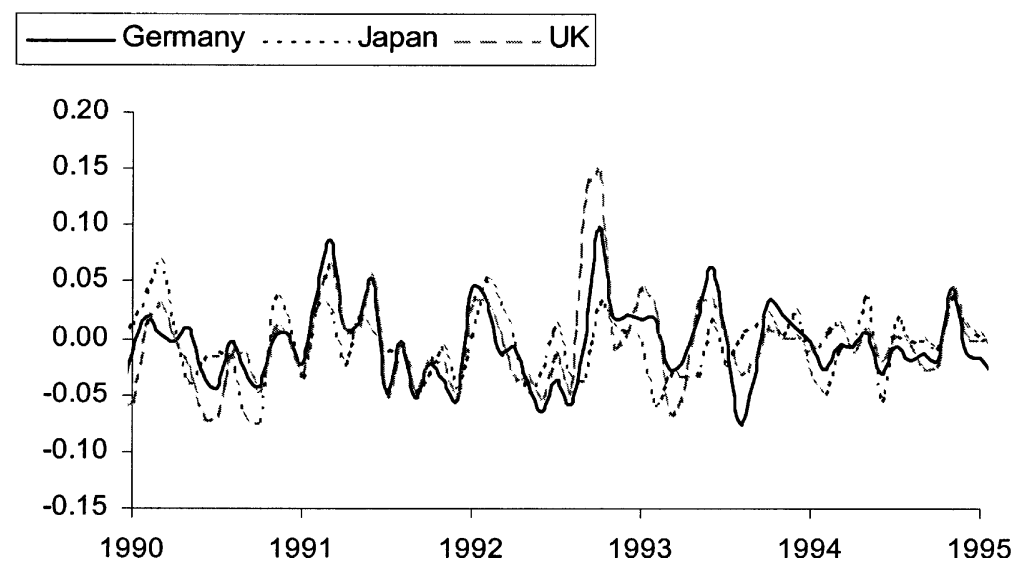

Fig. 1. The forward prediction error, jointly plotted for the three exchange rates

$\left(u_{t}-\gamma u_{t-1}\right)+\eta_{t-1}$ is correlated with $\left(u_{t+1}-\gamma u_{t}\right)+\eta_{t}$, the latter term can be represented by a moving average process of order one. See the Appendix A for a detailed derivation. Consequently, the eq. (9) represents an $\operatorname{ARMA}(1,1)$ model, which can be expressed as

$$
\mathrm{PE}_{\mathrm{t}}=\alpha+\gamma \mathrm{PE}_{\mathrm{t}-1}+v_{\mathrm{t}}+\psi v_{\mathrm{t}-1}
$$

where $\alpha$ equals $\mathrm{d}(1-\gamma), v$ is an uncorrelated, zero mean process, and $\psi$ is a firstorder moving-average coefficient. The model presented in eq. (10) can be estimated straightforwardly by maximum likelihood techniques. In Fig. 2, we plot the time series of fitted risk premia that are implied by the maximum-likelihood point estimates for the univariate models. This joint plot indicates that there appears to be a

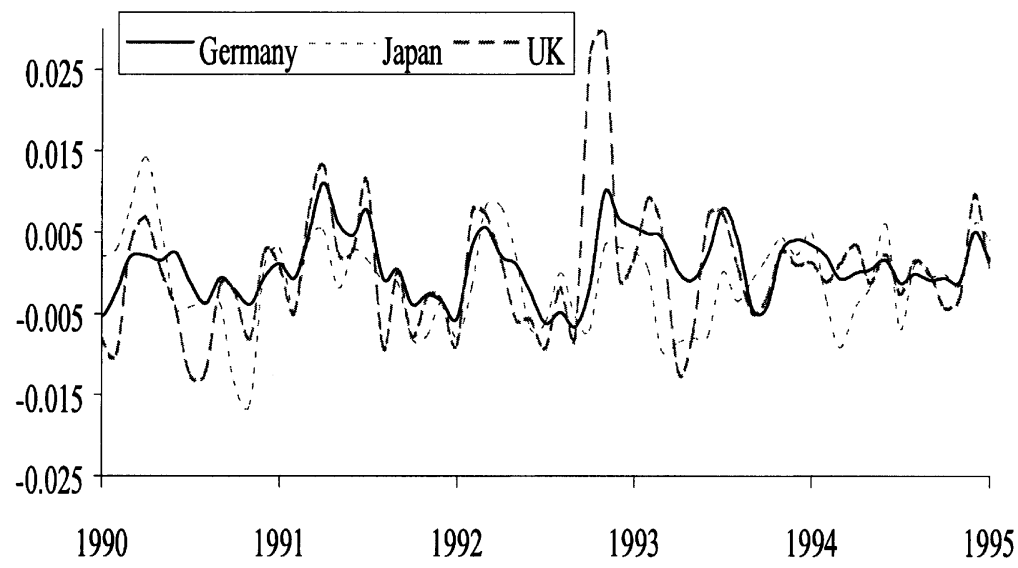

Fig. 2. The estimated risk premium from univariate models 
considerable common component in these preliminary measurements of the risk premia.

We now turn to the pooled risk premium model. As was mentioned in Section 2, we impose the normalization $\theta_{\mathrm{BP} / \mathrm{US}}=1$. Thus the 'exposures' to the common component for the other currencies will be expressed relative to the degree of exposure for the sterling/dollar exchange rate. Table 5 reports the maximum-likelihood estimation results of fitting the model in eqs. (5)-(8). The likelihood function was evaluated with the use of Kalman filtering techniques.

In Table 5, all coefficients that describe the time-varying risk premia are now highly statistically significant. The coefficient of central interest is $\gamma$. It governs the dynamics of the common component in the risk premia. Its estimated value $(0.196)$ is significantly positive, indicating that there is persistence in the common factor. The $\theta$ 's, which describe the 'exposures' of the individual currencies to the common factor, are also positive (as is to be expected) and significant. It is interesting to note that the point estimates of the $\theta$ 's are different for the three currencies. Likelihood ratios tests (not shown) indicate that they are also statistically significantly different from each other. The point estimates of these coefficients indicate that the dollar risk premium for the pound sterling reacts about twice as strongly to movements in the common factor as the Japanese yen. The German mark takes an intermediate position.

In order to get a visual impression of the dynamics, the time-dependent common component of the risk premia is plotted in Fig. 3 for the entire data set. Summary statistics on the behavior of the residuals of the full panel data model are provided in Table 6.

It is interesting to compare the autocorrelation statistics in Table 6 with their counterparts for the change in the spot rate in Table 4. For all currencies, the autocorrelation that was significantly present in the change of the (log of the) spot rate is accounted for by the panel data model, as evidenced by the negligible degrees of

Table 5

Maximum-likelihood parameter estimates for the full panel data model, $\mathrm{Y}_{\mathrm{t}+1}=\mathrm{d}+\mathrm{X}_{\mathrm{t}}+\theta \lambda_{\mathrm{t}}+$ $\mathrm{u}_{\mathrm{t}+1}, \quad \mathrm{u}_{\mathrm{t}} \sim \mathrm{N}(0, \Sigma) \lambda_{\mathrm{t}}=\gamma \lambda_{\mathrm{t}-1}+\eta_{\mathrm{t}}, \quad \eta_{\mathrm{t}} \sim \mathrm{N}\left(0, \xi^{2}\right)$

\begin{tabular}{lll}
\hline & Parameter estimate & Asymptotic standard error \\
\hline $\mathrm{d}_{\mathrm{DM} / \mathrm{USS}} \times 10^{2}$ & 0.157 & 0.285 \\
$\mathrm{~d}_{\mathrm{JY} / \mathrm{US}} \times 10^{2}$ & 0.065 & 0.278 \\
$\mathrm{~d}_{\mathrm{BP} / \mathrm{US}} \times 10^{2}$ & 0.106 & 0.311 \\
$\gamma$ & $0.196^{* *}$ & 0.068 \\
$\theta_{\mathrm{DM} / \mathrm{US}}$ & $0.711^{* *}$ & 0.238 \\
$\theta_{\mathrm{JY} / \mathrm{US}}$ & $0.523^{* *}$ & 0.184 \\
$\theta_{\mathrm{BP} / \mathrm{Us}}$ & 1.000 & - \\
$\xi^{2} \times 10^{2}$ & $0.134^{* *}$ & 0.048 \\
\hline
\end{tabular}

Note. -DM $=$ German mark, JY $=$ Japanese yen, $\mathrm{BP}=$ British pound, US $=$ U.S. dollar.

* Significant at the $5 \%$ level.

** Significant at the $1 \%$ level. 


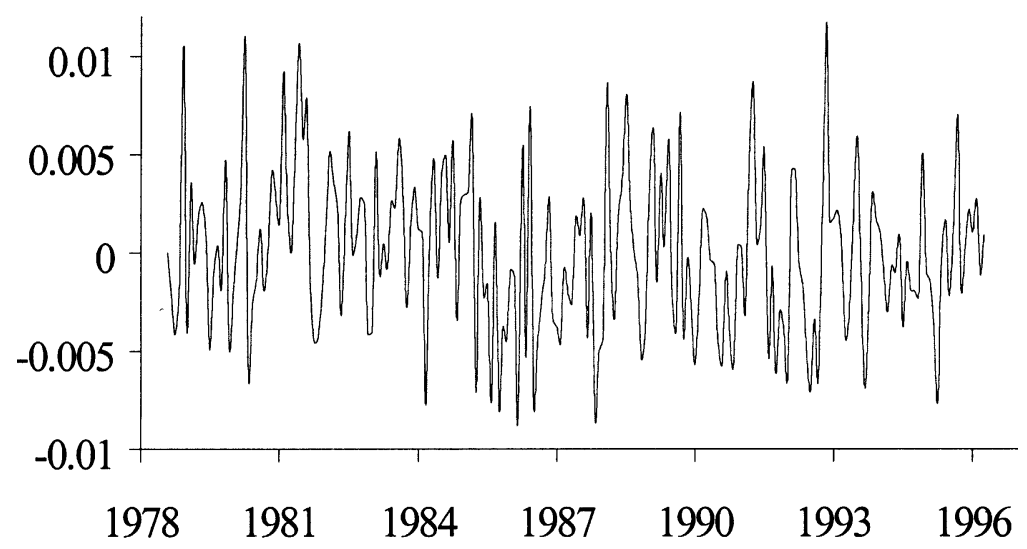

Fig. 3. The common time-varying component of the risk premia, $\lambda_{t}$

Table 6

Summary statistics on the residuals of the full panel data model

\begin{tabular}{llll}
\hline & DM/US & JY/US & BP/US \\
\hline Minimum & -0.087 & -0.117 & -0.118 \\
Maximum & 0.110 & 0.109 & 0.140 \\
Mean & 0.000 & 0.000 & 0.000 \\
Standard Deviation & 0.037 & 0.038 & 0.037 \\
Skewness & 0.222 & -0.172 & 0.306 \\
Kurtosis & 2.961 & 3.342 & $3.861^{* *}$ \\
Auto-correlation & -0.000 & 0.132 & 0.002 \\
DW-statistic & 1.993 & 1.734 & 1.994 \\
\hline
\end{tabular}

Note.-DM = German mark, JY = Japanese yen, $\mathrm{BP}=$ British pound, US = U.S. dollar. Data are annualized monthly data, expressed in percent.

* Significant at the $5 \%$ level.

** Significant at the $1 \%$ level.

residual autocorrelation. All three autocorrelation coefficients are statistically insignificant at conventional confidence levels. In all, the full panel data model appears to fit the dataset to a considerable extent. These results imply that the dynamics of the forward prediction errors can be attributed almost exclusively to the dollarrelated common component.

\section{Conclusion}

In this article, we have developed and estimated an econometric panel data model to capture the common dynamics in dollar risk premia in various forward foreign exchange rates. Interestingly, the common component in the dollar risk premium is highly significant and embodies a common pattern of positive serial 
correlation (persistence) in various dollar risk premia. In fact, the dollar-related common factor governs almost all of the dynamics of the forward prediction errors. Our evidence also suggests that the three different foreign currencies' dollar risk premia 'respond' to the common factor to different degrees. The pound sterling shows the strongest response, the Japanese yen the weakest, and the German mark takes a middle position.

\section{Appendix A}

In this appendix we provide technical background for the claims made in the paper regarding the model specification. First we demonstrate that the multivariate specification in eq. (1) is related to multiple univariate $\operatorname{ARMA}(1,1)$ specifications. Consider the specification

$$
\begin{aligned}
& P E_{i, t+1}=d_{i}+\theta_{i} \lambda_{i t}+\varepsilon_{i, t+1}, \quad \varepsilon_{i, t+1} \sim N\left(0, \sigma_{i i}\right), \\
& \lambda_{i t}=\gamma_{i} \lambda_{i, t-1}+\eta_{i t}, \quad \eta_{i t} \sim N\left(0, \xi_{i}^{2}\right)
\end{aligned}
$$

where $P E_{i, t+1} \equiv Y_{i, t+1}-X_{i t}$, From (A1) and (A2) it follows that

$$
P E_{i, t+1}-\gamma_{i} P E_{i t}=\left(1-\gamma_{i}\right) d_{i}+\theta_{i} \eta_{i t}+\varepsilon_{i, t+1}-\gamma_{i} \varepsilon_{i t} .
$$

Now define the process

$$
W_{i t} \equiv \theta_{i} \eta_{i t}+\varepsilon_{i, t+1}-\gamma_{i} \varepsilon_{i t}, \quad \varepsilon_{i t} \sim N\left(0, \sigma_{i i}\right) .
$$

Under the usual independence assumptions for the two error-term processes, an alternative representation holds which is of the form:

$$
W_{i t}=v_{i t}-\psi_{i} v_{i, t-1}, \quad v_{i t} \sim N\left(0, \sigma_{v_{i}}^{2}\right) .
$$

The variance and first-order autocovariance terms determine the relationship between the parameters in representation (A4) and (A5):

$$
E\left(X_{t} X_{t-j}\right)= \begin{cases}\left(1+\gamma_{i}^{2}\right) \sigma_{i i}+\theta_{i}^{2} \xi_{i}^{2}=\left(1+\psi_{i}^{2}\right) \sigma_{v i}^{2} & j=0 \\ -\gamma_{i} \sigma_{i i}=-\psi_{i} \sigma_{v i}^{2} & j \pm 1 \\ 0=0 & \text { otherwise. }\end{cases}
$$

It follows that an equivalent representation for (A1) and (A2) is given by

$$
P E_{i, t+1}-\gamma_{i} P E_{i t}=\alpha_{i}+v_{i t}-\psi_{i} v_{i, t-1}, \quad v_{i t} \sim N\left(0, \sigma_{v t}^{2}\right)
$$

where $\alpha_{i}=\left(1-\gamma_{i}\right) d_{i}, \sigma_{v i}^{2}=\frac{\gamma_{i}}{\psi_{i}} \sigma_{i i}$ and $\psi_{i}$ follows as the solution to the following quadratic equation: $\left\{\gamma_{i} \sigma_{i i}\right\} \psi_{i}^{2}-\left\{\left(1+\gamma_{i}^{2}\right) \sigma_{i i}+\theta_{i}^{2} \xi^{2}\right\} \psi_{i}+\left\{\gamma_{i} \sigma_{i i}\right\}=0$.

Hence it follows that an ARMA $(1,1)$ process may be written in a Kalman filter specification. In a multivariate setting, three ARMA $(1,1)$ processes may be represented by three equations similar to eq. (A1) and three equations similar to eq. (A2), only changing the subscripts to make reference to the alternative exchange rate under consideration. The assumption in the paper is that the three stochastic processes $\left\{\lambda_{i t}\right\}_{t=1}^{T} i=1,2,3$, may be represented by a single process indicated with 
$\left\{\lambda_{t}\right\}_{t=1}^{T}$. Note that this assumption is stronger than restricting the parameters in the alternative processes to be equal. In fact, the three processes are now assumed to be one process. This results in the multivariate specification of the model under consideration in this paper:

$$
\begin{aligned}
& P E_{t+1}=d+\theta \lambda_{t}+\varepsilon_{t+1}, \quad \varepsilon_{t+1} \sim N(0, \Sigma), \\
& \lambda_{t}=\gamma \lambda_{t-1}+\eta_{t}, \quad \eta_{t} \sim N\left(0, \xi^{2}\right) .
\end{aligned}
$$

Since the three ARMA(1,1) processes and the multivariate model in eqns (A8) and (A9) are not nested models, conventional Neyman-Pearson statistical hypothesis testing is not feasible.

\section{References}

Bekaert, G., Hodrick, R.J., 1992. Characterizing predictable components in excess returns on equity and foreign exchange markets. Journal of Finance 47, 467-510.

Cavaglia, S., Verschoor, W.F.C., Wolff, C.C.P., 1994. On the biasedness of forward foreign exchange rates: irrationality of risk premia? Journal of Business 67, 321-343.

Engel, C., 1996. The forward discount anomaly and the risk premium: a survey of recent evidence. Journal of Empirical Finance 3, 123-192.

Fama, E.F., 1984. Forward and spot exchange rates. Journal of Monetary Economics 14, 319-338.

Hodrick, R.J., 1987. The Empirical Evidence on the Efficiency of Forward and Futures Foreign Exchange Markets. Harwood Academic Publishers, Chur.

Huisman, R., Koedijk, K., Kool, C., Nissen, F., 1998. Extreme support for uncovered interest parity. Journal of International Money and Finance 17, 211-228.

Lewis, K.K., 1995. Puzzles in international financial markets. In: Rogoff, K., Grossman, G. (Eds.), Handbook of International Economics, vol. 3. North Holland, Amsterdam, pp. 1913-1971.

Nijman, T.E., Palm, F.C., Wolff, C.C.P., 1993. Premia in forward foreign exchange as unobserved components. Journal of Business and Economic Statistics 11, 361-365.

Wolff, C.C.P., 1987. Forward foreign exchange rates, expected spot rates, and premia: a signal-extraction approach. Journal of Finance 42, 395-406.

Wolff, C.C.P., 2000. Measuring the forward foreign exchange risk premium: multi-country evidence from unobserved components models. Journal of International Financial Markets, Institutions and Money 10, 1-8. 